\title{
Co-relations Between US Firms with Their Chinese "Supplier" Firms and the Co-movement of Their Stock Returns
}

\author{
Huiyan Xiao ${ }^{1, \mathrm{a}}$ \\ ${ }^{I}$ Bachelor Student at Computer Science Department, University College London, United Kingdom \\ axhy2109@163.com
}

\begin{abstract}
The paper investigated whether synchronised movements of stock returns happen between US "customer" firms with their Chinese "supplier" firms. Using stock return data of related US and Chinese firms between 2000 to 2019, through OLS regression and Fama-MacBeth regression, I found that there is a prove of the existence of co-movements. The paper also found that during early period of that 20 years $(2000$ - 2009), the co-movements are stronger than later period $(2010-2019)$.
\end{abstract}

Keywords: customer firm, supplier firm, US and Chinese stock market relations, co-movements of stock returns.

\section{INTRODUCTION AND BACKGROUNDS}

As the world's first and second economic entities, the United States and China have top influences on the globalisation and economy as a whole. US and China are one of each other's most important trading partners nowadays. Within different trading patterns, one of the most common schemes is a "customer" firm in the US with several "supplier" firms in China. That produces "co-relations" between them.

For instance, a furniture company in the US may have a "supplier" firm in China which offers raw materials, and another firm in China as well which offers processing and assembling services. The furniture company just need to provide a blueprint of the furniture. Another example is if you look at any Apple's product, on the package, there is a small sentence that says, "Designed by Apple in California, Assembled in China." This is a typical co-relation with a US firm acting like a "customer", and a Chinese supplier (provide assembly services to the "customer"). This structure formed because of both absolute and comparative advantages. There are tons of examples over the real market. The corelations of these "customer" firms and "supplier" firms are worth to consider.

Although in some areas, US firms with high mechanisation have absolute advantage, however, in most cases, Chinese firms and industries have good labour productivity and high performance-cost ratio, while US firms have high technology skills and demand, results in comparative advantages. In this case, Chinese firms generally are good at raw materials, quantitative production and assembly, while US firms usually are skilled in high-tech final products and overall designs. These features with co-relations were formed many years ago, and in modern years, with narrow in technology skill gaps and increase in labour costs in China, more and more firms chose to seek manufactures in other countries with lower labour costs like Vietnam. However, there are still tons of products that are "made in China" since this trading pattern exists for many years, and it takes time to react to the latest changes. Also, China is still the most suitable country to produce products with relatively higher technology skill requirements such as the battery of electric cars.

The relationship between the US and Chinese firms are valuable to be investigated. Changes that happened financially or non-financially on the "customer" firms in the US is likely to have impacts on the Chinese "supplier" firms, more specifically, may lead to impacts on their supplier firms' stock price. For example, if a US firm that has several supplier firms in China recently received a subsidy by the state and has confirmed by the state government that the state will buy a certain amount of its goods. Then, there is a high possibility that its stock price 
will rise. Meanwhile, if the information mobility is perfect, the stock price of the supplier firms of it in China will also rise. This is mainly because the "customer" firm has a rise on its stock price and increase in the number of orders, trading between the "customer" firm and "supplier" firms will be enhanced, and that will increase the "supplier" firms' profit earned, which potentially may lead to a rise on their stock price. However, in the real world, the sharing of information is not perfect, which will lead to time lags between changes in stock prices. Also, there may have other factors in the real markets that may influence the synchronisation of stock price changes, even completely eliminate it. If we can find evidence, count in suitable parameters, that proves the synchronisation indeed exists, then we may take advantage of the co-relations. In detail, we may predict the changes of the stock prices of the "supplier" firms in China, using stock price changes of the "customer" firms in the US as well as other parameters.

For an example of the synchronisation movements of the stock prices, "Tesla" (TSLA, Nasdaq) is very popular in late 2020 (mid-November to mid-January next year). In the meantime, several Chinese "supplier" firms' stocks rose. As shown in Figure $1-4$.

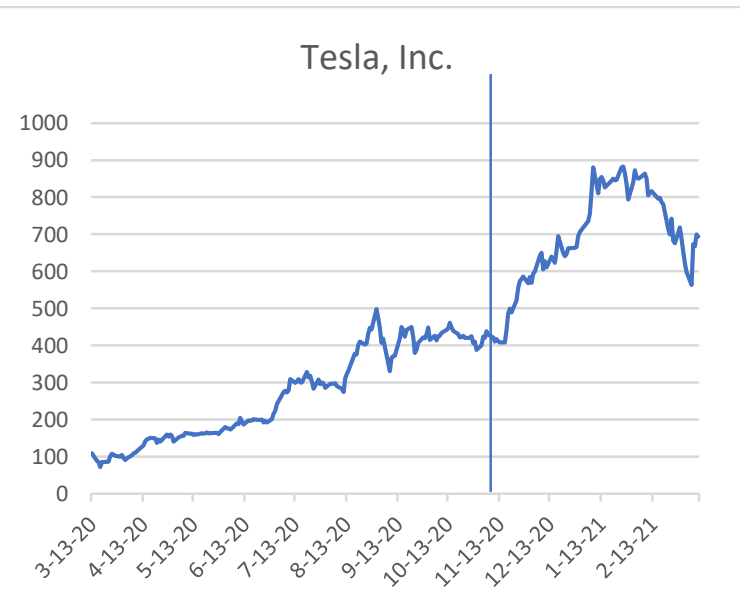

Fig. 1. Tesla's stock price changes

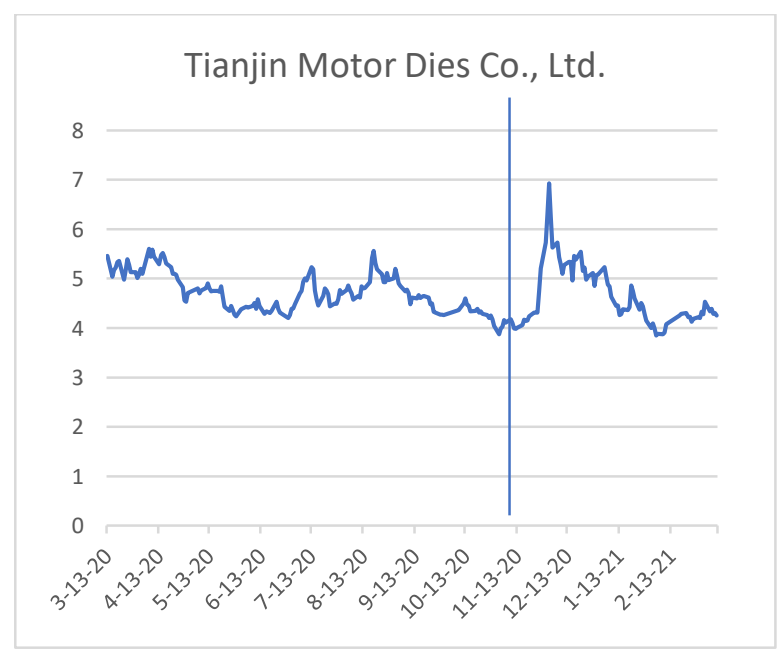

Fig. 2. Tianjin Motor Dies' stock price changes

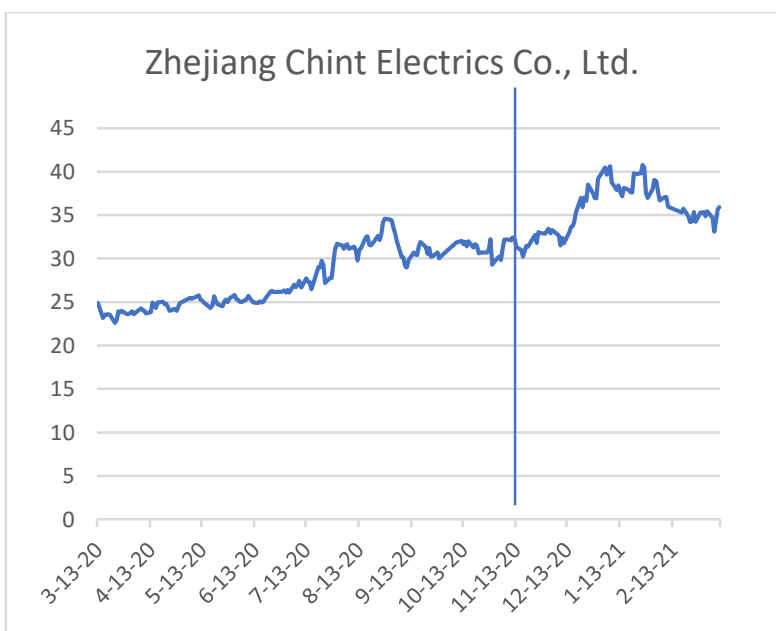

Fig. 3. Zhejiang Chint Electrics' stock price changes

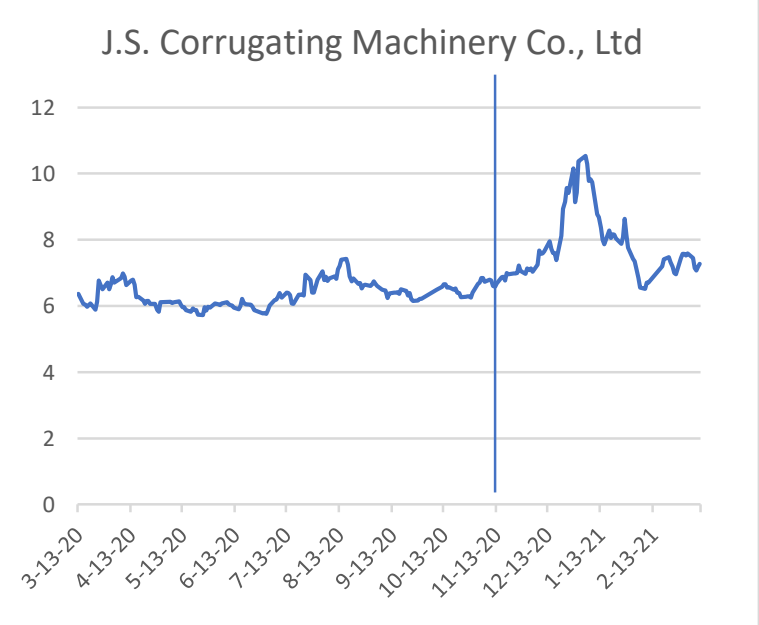

Fig. 4. J.S. Corrugating Machinery's stock price changes

From the charts, three "supplier" firms of Tesla in China all had a rise on their stock prices, although there are different time lags. Tianjin Motor Dies Co., Ltd. $(002510$, SZ) has relatively little time lag, while the other two (Zhejiang Chint Electrics Co., Ltd. (601877, SH) and J.S. Corrugating Machinery Co., Ltd (000821, SZ)) has significant time lags. If we can prove that overall, there is synchronised co-movements between US firms' stock returns with their Chinese supplier firms' stock returns, then we may take advantage of it by buying or selling Chinese stocks according to their US customer firms' stock returns changes before the usual time lags.

\section{LITERATURE REVIEW}

Base on other research papers reviewed, there are several traces of the co-relations and co-movements of stock returns.

"customer" firms can have impacts on the "supplier" firms. Possible factors are customer concentration, customer firms and supplier firms' dependences and number of customers. Lower customer concentration, 
higher dependences and large number of customers will lead to positive impact on suppliers, vice-versa. Either positive or negative impact shows potential stock return co-movements exist. [1] [2]

On the other hand, "supplier" firms can have impacts on the "customer" firms. Possible factors including online trading abilities, CSR as well as innovativeness. High trading abilities, CSR and innovativeness brings positive impact on customer firms, vice-versa. All these shows potential synchronised moves of stock returns exist. [3] [4] [5]

Finally, stock prices and return moves are predictable given some sort of "co-relations" between two firms, economically or generally. Different factors and degree of co-relations have different impact on prediction power. [6] [7] [8]

\section{DATA AND SAMPLE}

This paper investigates co-relations between US "customer" firms and Chinese "supplier" firms. For the dataset of US firms, I used data from CRSP. The Center for Research in Security Prices (CRSP) is a vendor of historical time series data on securities. Part of the University of Chicago's Booth School of Business, the CRSP is a nonprofit organization that is used by academic, commercial, and government agencies to access information such as price, dividends, and rates of returns on stocks. [9] The data schema I used contains each firm's permno and cusip for the matching purpose, and each firm's monthly return for each month. There are 1048575 lines of data in total, including 12091 US customer firms with their monthly returns. Although the time range of the data is between 2000 to 2019, however, some customers' return was missing for some years, reasons can be the business has not started yet or just data loss.

For the dataset of Chinese firms, the source that I used is CSMAR. CSMAR, short for China Stock Market \& Accounting Research Database, is a comprehensive research-oriented database focusing on China Finance and Economy. CSMAR was developed by Shenzhen CSMAR Data Technology Co., Ltd based on academic research needs, meeting with the international professional standards while adapting to China's features [10] The data schema for this contains symbol, isin and their monthly returns. There are 43071 lines of data, including 3953 Chinese supplier firms with their monthly returns. Possible data loss exists, same reason as the customer firms' data.

Finally, for the firms' relation part, I used data from Factset Revere. FactSet Revere specialty datasets offer a detailed mapping of company multi-industry exposures and competitors (Hierarchy, Hierarchy with Revenue, and RBICS); customers, suppliers, partners and competitors (Supply Chain Relationships); standardized revenues by geography ("GeoRev" Geographic Revenue Exposure). [11] The data schema for the customersupplier relation data contains customer firms" "cusip" and corresponding supplier firms" "isin", so I can figure out the relations between them. For this part of data, there are 3292 lines, each line shows a customer-supplier relation. I only include US customer firms with their Chinese supplier firms, not vice-versa.

For the generated dataset, I paired the customer firms and consumer firms base on the same month. The dataset only includes the year 2000 to 2019 which is 20 years, 240 months. However, for regression purposes, if for a particular month, a single supplier firm has two or more customers, then I take all the customer firm's returns and only put on one single averaged value. There are 30288 lines of data, 143 unique customer groups with different months' returns compare with the corresponding supplier firms.

\section{RESULT AND TESTING}

In short, there is strong relation shown if use OLS regression for the returns. Because this paper investigates in how Chinese supplier firms' stock return will be affected by their customer firms', so $\mathrm{Y}$ here is the supplier firms' stock return, and $\mathrm{X}$ here is the customer firms' stock return. Also, I applied Fama-MacBeth regression on them with customer's returns in ranking rather than the raw number. This is because of the existence of outliers of the customer firms' returns. Meanwhile, I eliminated the outliers of the suppliers' returns as well. The result shows a positive coefficient, with a fair $\mathrm{t}$-value.

In the beginning, I did simple OLS regression over the generated relation data with returns, the result is shown in Table 1.

Table 1. OLS regression result

SUMMARY OUTPUT

\begin{tabular}{lr}
\hline \multicolumn{2}{c}{ Regression Statistics } \\
\hline Multiple R & 0.08560836 \\
R Square & 0.00732879
\end{tabular}




\begin{tabular}{lr} 
Adjusted R Square & 0.00729602 \\
Standard Error & 0.162898 \\
Observations & 30288 \\
\hline
\end{tabular}

\begin{tabular}{lrrrrr} 
ANOVA & \multicolumn{1}{c}{} & & & \multicolumn{2}{c}{ Significance } \\
& $d f$ & SS & MS & $F$ & $F$ \\
\hline Regression & 1 & 5.93335552 & 5.93335552 & 223.598494 & $2.2462 \mathrm{E}-50$ \\
Residual & 30286 & 803.661965 & 0.02653576 & & \\
Total & 30287 & 809.59532 & & & \\
\hline
\end{tabular}

\begin{tabular}{lcccccc}
\hline & & \multicolumn{2}{c}{ Standard } & & & \\
& Coefficients & Error & \multicolumn{1}{c}{ Stat } & P-value & Lower 95\% & Upper 95\% \\
\hline Intercept & 0.01408408 & 0.00094035 & 14.977506 & $1.5631 \mathrm{E}-50$ & 0.01224096 & 0.01592721 \\
X Variable 1 & 0.16548674 & 0.01106697 & 14.9532102 & $2.2462 \mathrm{E}-50$ & 0.14379501 & 0.18717847 \\
\hline
\end{tabular}

From the regression result, we can see that there is a strong positive coefficient for the $\mathrm{X}$ variable, with a high $\mathrm{t}$ Stat value. At this point, we may say that there are tracks of the existence of the relations between stock returns. However, simple OLS regression is not enough because there are relations between sample data. The crossrelation between the customer firms (for supplier firms as well) within the same month is not a big deal since it is not that strong, and it's part of the consistency of the "industry" if two firms are within the same field. The problem is for a single firm's return data in different months, there must exist relations, and it is relatively strong.

To resolve this problem, I used Fama-Macbeth regression. In the meantime, I found that outliers exist for both customer firms' return data and supplier firms' return data. To eliminate the impact of outliers, I grouped the customer firms base on their returns. There are 3 groups in total, according to different firms' returns, group $1<$ group $2<$ group 3. Instead of customer firms' returns, I use 1, 2 or 3 as $\mathrm{X}$ for the Fama-MacBeth regression. By doing this, we can reduce the outliers' impact significantly since they will be in group 1 or 3 , which only a single integer to represent the value. A problem with using this method is that the coefficient will not have any meanings except positive/negative. However, even if we use the raw return value, the greatest meaning of the coefficient is still the sign of it since the dataset includes tons of different firms within many industries, it is very hard to use the coefficient itself to produce some meaningful results. As for the outlier returns of the supplier firms, I dropped the biggest $0.5 \%$ of data as well as the smallest $0.5 \%$, to lower the impact of the outliers. The result is as Table 2 .

There is a positive coefficient with t value of 2.27 which shows significancy. From this regression test, we can say that predictability does exist. More specifically, overall, Chinese "supplier" firms' stock return has relations with their US "customer" firms' stock return, given that they have customer-supplier relation. Given the stock return changes of a US firm, we have some prediction power on its Chinese supplier firms' stock return changes, there is a positive correlation.

Table 2. Fama-MacBeth regression result

Fama-MacBeth (1973) Two-Step procedure

$\begin{array}{llr}\text { Number of obs } & = & 30288 \\ \text { Num. time periods } & = & 240 \\ \text { F }(1,239) & = & 5.16 \\ \text { Prob }>\text { F } & = & 0.0240 \\ \text { avg. R-squared } & = & 0.0129\end{array}$

\begin{tabular}{lcccccc}
\hline \multicolumn{1}{c}{ Supplier return } & Coef. & $\begin{array}{c}\text { Standard } \\
\text { Error }\end{array}$ & $\mathrm{t}$ Stat & $\mathrm{P}>|\mathrm{t}|$ & Lower 95\% & Upper 95\% \\
\hline customer return & & & & & & \\
rank & 0.0021068 & 0.0009273 & 2.27 & 0.024 & 0.0002802 & 0.0039334 \\
cons & 0.0114159 & 0.0062359 & 1.83 & 0.068 & -0.0008684 & 0.0237002 \\
\hline
\end{tabular}


Furthermore, I also investigated two different time periods within the 20 years, from 2000 to 2009 and from 2010 to 2019, to see the change of t-value which can infer the strength of the co-movements. Table 3 and Table 4 shows Fama-MacBeth regression results of the year 2000 - 2009 and $2010-2019$ respectively.

From the results, we can see that the early period $(2000-2009)$ has a larger $t$ value than the later period $(2010-2019)$. One of the most important reasons behind this might be that in the early period, the co-movement of returns are stronger since the Chinese market is not as efficient as in the later period. Lots of areas in the Chinese market are related to or rely on the US market. However, in the later period, the Chinese market becomes more efficient, segmentation is stronger between Chinese firms and US firms. Also, the Chinese government started to pay more and more attention to developing the "Asian economic environment", enhance trading with ASEAN (Association of Southeast Asian Nations), the dependency on the US market has reduced.

Table 3. Fama-MacBeth regression on the year 2000 - 2009

Fama-MacBeth (1973) Two-Step procedure

$\begin{array}{lrr}\text { Number of obs } & = & 8863 \\ \text { Num. time periods } & = & 120 \\ \text { F }(1,119) & = & 4.43 \\ \text { Prob }>\text { F } & = & 0.0373 \\ \text { avg. R-squared } & = & 0.0198\end{array}$

\begin{tabular}{lcccccc}
\hline \multicolumn{1}{c}{ Supplier return } & Coef. & $\begin{array}{c}\text { Standard } \\
\text { Error }\end{array}$ & t Stat & $\mathrm{P}>|\mathrm{t}|$ & Lower 95\% & Upper 95\% \\
\hline $\begin{array}{l}\text { customer return } \\
\text { rank }\end{array}$ & 0.0033744 & 0.0016023 & 2.11 & 0.037 & 0.0002016 & 0.0065472 \\
cons & 0.0134855 & 0.0095847 & 1.41 & 0.162 & -0.0054931 & 0.0324642 \\
\hline
\end{tabular}

Table 4. Fama-MacBeth regression on the year 2010 - 2019
Fama-MacBeth (1973) Two-Step procedure

$\begin{array}{llr}\text { Number of obs } & = & 21425 \\ \text { Num. time periods } & = & 120 \\ \text { F }(1,239) & = & 1.39 \\ \text { Prob }>\text { F } & = & 0.2415 \\ \text { avg. R-squared } & = & 0.0069\end{array}$

\begin{tabular}{lcccccc}
\hline \multicolumn{1}{c}{ Supplier return } & Coef. & $\begin{array}{c}\text { Standard } \\
\text { Error }\end{array}$ & $\mathrm{t}$ Stat & $\mathrm{P}>|\mathrm{t}|$ & Lower 95\% & Upper 95\% \\
\hline $\begin{array}{l}\text { customer return } \\
\text { rank }\end{array}$ & 0.0011313 & 0.0009611 & 1.18 & 0.242 & -0.0007718 & 0.0030343 \\
cons & 0.0087469 & 0.0079597 & 1.10 & 0.274 & -0.0070142 & 0.0245079 \\
\hline
\end{tabular}

\section{CONCLUSION AND REAL EFFECTS}

In conclusion, there are co-movements between US firms' stock return with their Chinese supplier firms' stock return overall, with a stronger relation in the early period (2000 - 2009) compared to the later period (2010 - 2019). The predictability does exist. OLS and FamaMacBeth regressions have proved the result mentioned above.

Through these features, we may take advantage of the prediction power, to estimate the change of stock returns of Chinese firms based on their US customer firms' stock return moves. The paper has stated that there is a significantly positive relation between them. In the future, through further studies, if we can estimate the exact degree of change in supplier firms' return according to their customer firms, then produce a well-structured portfolio of stocks in the Chinese stock market, with the help of their US supplier firms' stock return moves, we may gain advantages through the potential time lag of the return changes.

\section{REFERENCES}

[1]Y. H. Kim, J. Sup. Chain Man., 53, 26-40, (2016)

[2]H. Li, G. Zheng, D. Li, China J. Acco. Stud., 5, 326343, (2017)

[3]D. R. Deeter-Schmelz, A. Bizzari, R. Graham, C. Howdyshell, J. Sup. Chain Man., 37, 4-10, (2006)

[4]H. (A.) Chen, K. Karim, A. Tao, Adva. Acco., 52, 100516, (2021)

[5]S. M. Wagner, Indus. Mar. Man., 39, 1139-1149, (2021)

[6]L. Cohen, A. Frazzini, J. Fin, 63, 1977-2011, (2008) 
[7]F. Wen, Y. Yuan, W. Zhou, Int. J. Fin. Econ., 26, 914918, (2019)

[8]J. Cao, T. Chordia, C. Lin, J. Fin. Quant. Anal., 51, 1689- $1717,(2016)$

[9]D. Liberto, Investopedia, (2021) [Online]. Available: https://www.investopedia.com/terms/c/crsp.asp. [Accessed 6 July 2021].

[10]Shenzhen CSMAR Data Technology Co., Ltd, [Online]. Available: https://www.gtadata.com/. [Accessed 6 July 2021].

[11]The Wharton School, University of Pennsylvania, [Online]. Available: https://wrdswww.wharton.upenn.edu/pages/about/datavendors/factset/. [Accessed 6 July 2021]. 